\title{
Education, Health, and Public Service in Indonesia: An Islamic Economics View
}

\author{
Noor Muhariah Dorojatun, S.El ${ }^{*}$ \\ 1 Yetro Sinseng Street No 7 Muara Teweh, Central Borneo, Indonesia \\ *Corresponding author. Email:enemde9008@gmail.com \\ Manuscript submitted August 04, 2014; accepted October 13, 2017.
}

\begin{abstract}
The main object in this paper are two. First, to determine the suitability of laws on education and health to the government expenditure of Indonesia in Islamic economics view. Second, to devise guidelines for national policymakers in the implementation of government expenditure in education and health which gives utmost priority to public service. The distinctive feature of this paper is not only to see the increasing government expenditure and public services but in additional to implement the maximum government expenditure in education and health, there needs to be a minimum standard service which we see not only from the laws but from Islamic economics too. This paper contains as follow: section 1 commences with the sneak peak of Islamic economics, the increasing of government expenditure phenomenon, and empirical study about health and education. Section 2 addresses the state expenditure in Islam, the definition of government expenditure according to la $\mathrm{W}$, quality of services in Islam, and the definition of public services. Section 3 discusses education and health expenditure according tolaw and the minimum service standard for both and last, Section 4 is the conclusion.
\end{abstract}

Keywords: education, health, public service, government expenditure.

\section{Introduction}

Islamic economics, in fact, a new reality in the modern scientific world today. In the period of last 50 years, he continued to grow perfecting itself in the midst of a diverse array of social and economic systems. Indeed Islamic economics has been practiced to perfect the days of the Prophet Muhammad to the heyday of the Daulah Islamiyah a few centuries ago, long before the Western people find economic concept known as a conventional economic system. The presence of Islamic economics is not a form of reaction to the domination of capitalism or socialism at the time. But perfection is a totality of Islam itself.

This day I have perfected for you your religion and completed My favor upon you and have approved for you Islam as religion. (QS Al - Maidah: 3)

To further the development of an economy needs to be a policy held by the government, be it action or strategy that the economy is running continuously strived forward, in the absence of an economic weakness that causes inflation, unemployment and so forth. But if the government revenue reduced then the government should also reduce expenditure. Conceptually types of government revenue and government expenditure allocation in conventional economics and Islamic economics is almost the same. However, the goal to be achieved is a bit different, given the 
principle of budget management in Islam is always on the show to create justice, so that everything should base on the commands of the Qur'an Hadith. Whereas in conventional economic budget policy only as a complement monetary policy to the achievement of macroeconomic objectives.

Based on basic data the State Revenue and Expenditure Budget from the year 2008-2015 there is a tendency that happens, where spending or government expenditure is increasing from year to year, except in 2009. This increase can see in the image below:

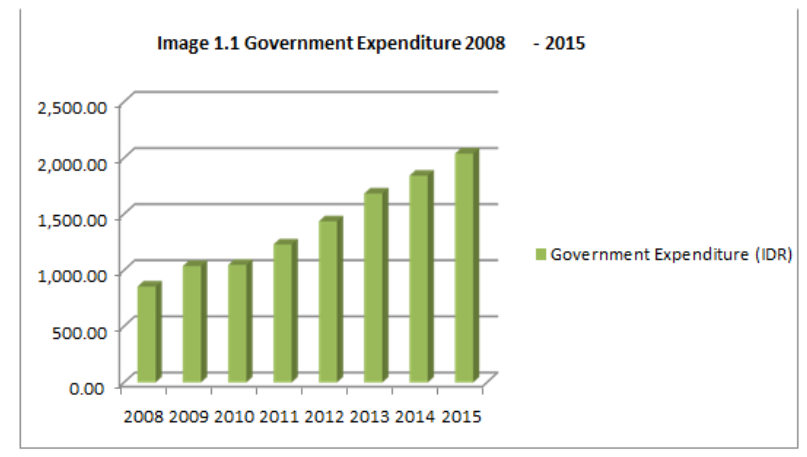

Source: State Revenue and ExpendituBerdget of Indonesia

The data shows that there is a tendency increase in spending from year to year. Expenditure is dominated by central government expenditures fluctuated. Based on its function, central government spending dominated by public services and organizations based there biggest shopping at the Ministry of Education because according to the Law that the education budget should be at $20 \%$ of the total State budget. The condition is happening because education in the sense of the intellectual life of the nation is an objective state of Indonesia as stated in the preamble of the Constitution of 1945, fourth paragraph.

The level of welfare reflected in the fulfillment of people's basic rights and equitable distribution of national development results. For the welfare indicator of the fulfillment of basic rights can be seen from how much people's access to health, education, and housing, as well as the availability of basic infrastructures such as roads, energy, electricity and water resources. Increased public access to health done through health education programs, prevention, treatment, and rehabilitation, to improve people's access to health care universal and quality. The government will also improve the public health insurance and labor insurance program will launch (Jampersal) to further improve the access and quality of health of pregnant women and childbirth.

Meanwhile, strengthening access to education is directed through the expansion and equalization Compulsory Basic Education 9 Years, expanding and improving the quality of secondary education and higher education, non-formal education, early childhood education, as well as improving the quality of education and educational services at all levels of education. Fulfillment of various people's basic rights in the areas of health, education, housing, as well as the availability of electricity and water, but aims to improve the welfare of the community, basically also intended as a strategy and policy direction to reduce the inequality in income distribution in society.

Therefore, the concept of Islamic economics in running economy is not far from the concepts that have been taught by the Prophet. The principles of justice that should play by the government covering various sectors, ranging from religion, education, health, law, politics, economics, facilities, and infrastructure. So that justice can be achieved, then the state can classify the utilization of resources by the level of interest and the availability of economic resources owned by each region. Without allocation-wise, there will be inefficiencies in the use of economic resources. This 
inefficiency will bring a broad impact on space and time dimensions.

\section{Methods}

All trading SMEs are located in Malang Region, East Java, and meet the criteria based on the Law of the Republic of Indonesia No. 20 of 2008 on Micro, Small and Medium Enterprises (MSMEs) [12]. The SME standards under the law are as follows.

Table 1. SME Standards based on the Law of the Republic of Indonesia No. 20 of 2008 on MSMEs

\begin{tabular}{ll}
\hline Classification & Daily Sales Turnover \\
\hline Micro & $<$ Rp. 900 thousand \\
Small & Rp. 900 thousand $-<$ Rp. 7,5 thousand \\
Medium & Rp. 7,5 thousands $-<$ Rp. 150 thousand \\
\hline
\end{tabular}

Trading SMEs as research subjects are selected using random sampling. All selected trading SMEs must have the motivation and commitment to improve and develop the accounting information system in their companies. Final trading SMEs as the focus of research is 12 SMEs, while the object of the study concentrated on the accounting information system applied in the trading SME.

The study was conducted using mixed methods that bring together the quantitative and qualitative data to obtain a comprehensive analysis of the research problem [13]. Quantitative and qualitative data are collected through observation, interviews, questionnaires, and documentation to illustrate the implementation of the accounting information system applied in trading SMEs. The data gathered in this research is in the form of primary data and secondary data. Primary data is obtained directly by researchers from respondents or informants to be reprocessed to find the answers. Secondary data is the data obtained from the second party or data that does not need to be reprocessed by the researchers. The secondary data includes the organizational structure, job descriptions, chart of accounts, journals, procedures, cost accounting, documentation, and accounting policies of the organization.

Data analysis performed in four steps. First, creating research note during the fieldwork. Second, grouping a similar data from interview results associated with the implementation of accounting information systems in trading SMEs. Third, performing an analysis of the obtained data and used it as the basis to evaluate the weaknesses and the strength of the system implemented by SMEs. Fourth, providing the recommendations to improve accounting information system on the practical side, healthy business practices and the sharia implementation based on the study of Qur'an and Hadith.

\section{Result and Discussion}

Islamic principles of fiscal policy and the budget aims to develop a society which based on balanced distribution of wealth by placing the material and spiritual values at the same level, from all religious texts in past, the Quran was the only book that put the right command State policy regarding revenue expenditure, this statement reflects a new draft of the assessment of fiscal policy issues in making government spending, and in obtaining government revenue, the determination of the type, achieve certain distinctive.

Further research by Marijn Verhoeven, Victoria Gunnarsson, and Stéphane Carcillo with the title Education and Health in G7 Countries: Achieving Better Outcomes with Less Spending in which 
research is conducted there in 2005 aimed to assess the level of efficiency in the education and health sectors and find the relationship between the difference the efficiency of various countries, as well as institutional policy factors. Public sector inefficiency of government spending is going on there G7 countries because of lack of efficacy in resources, such as teachers and medical personnel (physician).

Research by Mohammed B Yusoff with title Zakat Expenditure, School Enrollment and Economic Growth in Malaysia results showed that the $10 \%$ increase in spending zakat could boost real GDP growth amounted to $0.138 \%$ and $10 \%$ increase in enrollment could increase real GDP growth amounted to $0,023 \%$. These results indicate that spending zakat and enrollment ratio has a positive effect on the level of ability of real GDP growth.

Research by Fuad Abdullah Al Omar with the title Growth Of Public Expenditure And Bureaucracy In Kuwait. The results showed the same conclusion in the field of healthcare expenditures and the number of employees in this sector, which can interpret the increase in health spending and the number of health workers is justified. Increased per capita income indicates the availability of resources and increasing population shows need for improvements in public services such as education, health, and safety.

\subsection{State Expenditure in Islam}

Some Muslim scholars opinion regarding state expenditures includes: Ibn Sina recommends the count of budget carefully, both on the revenue and expenditure. To expenses that are not mandatory, everyone should be careful to avoid spending money uselessly. Compulsory expenditure according to Ibn Sina is:

a. Living, that all costs necessary to live an individual.

b. Good deed, that any acts of charity to others either society or the state.

According to Ibn Sina expenditure obligations to society and the state, this obligation consists of three kinds:

a.Zakat, the obligatory expenditure of wealth, either in the form of wealth such as gold and silver, money or wealth in the form of companies such as agricultural products, livestock, trade and others. Zakat should levied for the purpose used state and society, both general and to help the misery and destitution of the people.

b. Shadaqah, that expenditure required to help the needy, the poor, and other social enterprises.

c. Good deed, that general aid granted to all persons or any entity that needs it, this part is called charity ma'ruf

There is five state expenditure written Abu Yusuf in Al-Kharaj, among them are:

a. Salaries of civil servants, judges, and tax manager. Public services in Islam that must be borne by the state not only include sector salaries but for the whole of society deserving such as education, health, justice, water, lighting and so forth. The state is obliged to pay all employees who have made the task of public service with a decent salary within a class.

b. Facilities army for defense. Explained that the military defense facilities consisting of the Muslims as a whole at the time of the Prophet Muhammad not provided. Meanwhile, during the caliphate of Abu Bakr, he apportioned to all Muslims. At the time of Umar bin Khattab division not generalized.

c. Fulfillment of basic needs of society. This policy is the foundation of a country's economic policy. Zakat is a social security institution in Islam because Islam is not only called on his.

People to implement social security, but has set up a charity institution to handle such problems. d. Infrastructure projects. State responsible finance infrastructure projects, such as river treatment 
and excavation, so that irrigation smoothly so that the results become abundant. Countries using the budget to fund the infrastructure projects that the benefits are felt by the public, also, to have added value in the form of an increase in state revenue, since this kind of project has an investment value that will increase the national income and state revenue.

e.Mustahik zakat. Special revenue in Islam specifically allocated to certain groups that correspond with those contained in the Qur'an and Sunnah is a treasure obtained from other than a fifth zakat ghanimah

Based on the economic analysis of the history of public expenditure in time of the Prophet and the first four Rosyidin, in essence, main principles allocation of public funds is to increase the highest maslahah. In general, the expenditure can categorize into four:

a. Empowerment of the poor and converts. These funds were taken from the zakat and ushr

b. The cost of routine administration. These funds generally were taken from kharaj, fay, jizya and ushr.

c. The cost of development and social welfare. These funds were taken from other funds, khumuz, and alms.

d. Other costs, such as emergency expenses, maintenance of abandoned children and so on. These funds were taken from waqf, public debt and so on.

\subsection{State Budget Revenue and Expenditure}

According to the book basis of budgetary revenue and expenditure (APBN), Revenue and Expenditure Budget (APBN) is the law, so it is an agreement between the government and the House of Representatives (DPR). As mentioned in Article 23 of the Constitution of 1945that: Budget as a form of state financial management is determined annually by law and carried out in an open and responsible for the greatest prosperity of the people. In Article 1 of Law No. 17 the Year 2003 on State Finance, which is defined as the state budget is the Parliament approves the state government's annual financial plan. Budget lists are containing a systematic and detailed plan of receipts and expenditures for the fiscal year (January 1 to December 31, the state budget, changes in the state budget, and the accountability of the state budget every year stipulated by the Law.

In the explanation of Law No. 17 of 2003 on State Finance, explained: allocation function implies that the state budget should gear to reducing unemployment and waste of resources, and to improve the efficiency and effectiveness of the economy; distribution function implies that state policy should take fairness and compliance; stabilization function means that the government budget into a tool to maintain and seek balance economic fundamentals.

Expenditure is all state expenditures in a budget year that reduces the equity funds smoothly and is a state obligation, and will not re-obtained payment by the state. The amount of expenditure listed in the budget is the highest limit, so it cannot exceed. Shopping this country has a strategic role in supporting the accelerated development of an inclusive and sustainable in achieving and improving people's welfare. Expenditure comprises of Central Government spending and transfers to the regions. Central Government spending has a function as a stabilizer for the economy, while the economy in recession, it is the policy of the Central Government Expenditure on the expansionary can give stimulation of economic growth and stability and strengthen macroeconomic fundamentals. Conversely, when the economy is in a state too expansive, Central Government Expenditure policy can contribute to stabilizing the economy towards more conducive conditions.

Central Government Expenditure by Function: public service function, the function of defense, 
public order and safety functions, the economic function, environmental function, the function of housing and public facilities, health function, the function of tourism, religious function, the function of education, and social protection functions. Central Government expenditures by type are personnel expenditure, spending on goods, capital expenditures, debt interest payments, subsidies, grants expenditure, social assistance, and other expenditures. Details of the stricken transfer budget are balancing funds consists of revenue sharing; general allocation fund; special allocation funds; and the special autonomy funds; special autonomy fund and fund adjustment.

\subsection{The Quality of Services in Islam}

Islam teaches that if you want to give the results of operations both in the form of goods and services should provide quality, do not give bad or not qualified to others. As described in the Quran:

O you who have believed, spend from the good things which you have earned and from that which we have produced for you from the earth. And do not aim toward the defective from that place, spending [from that] while you would not take it [yourself] except with closed eyes. And know that Allah is Free of need and Praiseworthy. (QS Al - Baqarah: 267)

According to Thorik Utus $G$. and H. (2006: 77), the importance of providing a quality service due to service (service) not merely delivered or serve. Service means to understand, comprehend, and feel so delivered will share the heart of consumers and ultimately strengthen the position in the consumer mindshare. With the heart share and mindshare embedded, consumer loyalty to a product or business enterprise will not be hesitant. According to mainstream schools in Adiwarman Karim (2003: 49) explains the differences in conventional and Islamic economics lies in solving the problem. Dilemmas of limited resources versus unlimited desires force people to make choices on his desire. Dimensional reliable (reliability) concerning the ability to provide the promised services are reliable and accurate. Services will be said reliable if the agreements that have been expressed accurately achieved. Precision and accuracy are what will foster consumer confidence in the institution service providers. In this context, God also wants each of His people to fulfill the promise that has made and declared as stated in the Qur'an:

And fulfill the covenant of Allah when you have taken it, [O believers], and do not break oaths after their confirmation while you have made Allah, over you, a witness. Indeed, Allah knows what you do. (QS An Nahl: 91)

\subsection{Education Expenditure}

Under article 49 that the allocation budget allocated to the education sector. Regarding budgeting, sector commensurate with the functions, it stipulated in the finance minister 101 / PMK.02 / 2011 on the Budget Classification. Budget classification by function, detailing expenditures by function and sub-function. The function itself has a sense of embodiment governance tasks in a particular field are carried out to achieve national development goals. Sub-function is a further elaboration of the function.

Use functions and sub-functions adapted to the duties and functions of each function. It uses associated with the activity (an elaboration of the program) is implemented, so that a program can use more than one function. Under the mandate of the law, the allocation of the education budget by $20 \%$ translates into budget allocation function of education. Based on data from the budget allocation per sub-function of education, allocation of higher education and basic education gets a larger portion of the sub-functions of the other. 
The education budget is the budget allocation function of education is budgeted through the state ministries/agencies, education budget through transfers to regions. The budget allocation for education through financing expenses, including the salaries of educators, but does not include service education budget, to finance the implementation of education are a responsible Government responsibility. The percentage of the education budget is the ratio of the total education budget allocation of the state budget. Education allocation is done three lines, namely:

First, through the Education Budget Allocation Central Government spending increased from Rp96,5 trillion in 2010 to Rp154.2 trillion in 2015. The budget allocation for education in the central government is used among others for the provision of scholarships for students/student underprivileged, rehabilitation of classrooms, the construction of new school units and new classrooms, as well as supporting infrastructure development and the provision of professional teacher allowance.

Second, the education budget allocation through transfers to regions, among others, consists of the budget allocated to certain budget sections, one of them in the application of minimum service standards of education. From the year 2010-2015, the budget allocation to education in a transfer area also experienced a very significant development, which is of Rp127, 7 trillion in 2010 to Rp254,9 trillion in 2015.

Third, the education budget through expenditure financing, from now on referred to national education development fund (DPPN) consists of endowment (endowment funds) education and education reserve fund, where BLU education manages the fund that Education Fund Management Institution (LPDP) which is work-unit from Ministry of Finance. While the Education Reserve Fund is the National Education Development Fund allocated in the state budget and APBN-P to anticipate the purposes of rehabilitation of educational facilities damaged by natural disasters.

\subsection{Health Expenditure}

Healthcare budgets constitute one important element in the implementation of priority health policy applied to RPJMN 2010-2014. Law No. 36 of 2009 Article 170 mentions health financing is aimed at providing sustainable health financing in sufficient amounts, allocated equitably, and utilized as effective and efficient to ensure the implementation of health development to improve the health of society as high. Source of health funding comes from the Government, local government, public, private and other sources of lain.12 Regulation illustrates that in the implementation of government health services, public and private sectors worked together in financing health.

Law No. 36 the Year 2009 on Health Article 171, also make a benchmark for the central government and local government in the allocation of health budget as follows:

1. Big Government health budget allocated a minimum of $5 \%$ (five percent) of the budget revenue and expenditure excluding salaries.

2. The health budget of the provincial government, district/city, allocated at least 10\% (ten percent) of budget revenue and expenditure excluding salaries.

3. The amount of the health budget as referred to in paragraph (1) and (2) priority to the interests of public services, which amount is at least 2/3 (two thirds) of the health budget in the budget revenue and expenditure and the budget revenue and expenditure. Law that should be a reference for the government in implementing health services for the community.

In 2010 health budget was only Rp 31584 billion, or 2.99\% of the state budget, then increased 
significantly in 2011 amounted to USD 43813 billion, or 3.56\%. The increase is due to the state budget for the year grew by $16.38 \%$ from the previous year, not because the government is more concerned with the health sector. Health budget increase this trend continues until the year 2014 amounting to Rp 67.500 billion.

Data released by the WHO (World Health Organization) budget per capita government spending on health care by using the average exchange rate (US \$) in 2011 amounted to only $\$ 32.4$ per year and put Indonesia at 151 out of 191 countries. This figure is far below neighboring countries amounted to $\$ 211.2$ rated Malaysia 92 , Thailand amounted to $\$ 152.3$ rated 107 or even the newly independent state of East Timor of $\$ 33.1$ one level above Indonesia.

\subsection{Minimum Service Standard for Education}

A minimum standard of basic education services (MSS) is a measure of the performance of basic education services, as well as a reference in planning and budgeting program targets the achievement of each district/city.

Minimum Service Standards (SPM) itself refers to the 27 conditions required for learning activities that should be realized by the local government. For example, SPM encourages the availability of textbooks, science labs and the existence of qualified teachers by the needs of all learners. SPM is very important because this standard reflects the assertion that every child in Indonesia has the right to education is minimal.

SPM is a clear manifestation of the assertion that every child in Indonesia have the right to get an education even at the most minimum level, wherever they live. This statement is very important, especially in the era of decentralization, where more than 500 Local Government is responsible for the provision of basic education for the children of Indonesia. Improving the quality of education so urgent to reduce the educational performance gap between regions. SPM help set a clear path for the government, schools and the community to be involved in efforts to achieve this goal.

\subsection{Minimum Service Standard for Health}

In the era of decentralization, the use of Minimum Service Standards (SPM) as a measure of performance becomes a necessity. Accountability is an absolute requirement that compels us to want not want to implement it in public service; health care is no exception to it.

Minimum service standard or commonly abbreviated as SPM is a minimum service standard that must be obtained by the public and becomes the program set by the central government, and local governments are required implementation by the resources and capabilities of the region.

In a large country like Indonesia, with a high degree of variability between regions required an SPM that also locally specific. Decree of the Minister of Health No. 1457 / Menkes / Sk / X / 2003 on Minimum Service Standards for Health in the District / City is a step forward in the effort to the accountability of public service performance.

Publishing Regulation of the Minister of Health No. 741 / Menkes / PER / VII / 2008 on Minimum Service Standards for Health in District / City annuls the previous policy is also very productive. Due to recent policies on health SPM is further simplify the performance indicators in the healthcare field.

\section{Conclusion}

The education budget is the budget allocation function of education is budgeted through the state ministries/agencies, education budget through transfers to regions, and the budget allocation for education through financing expenses, including the salaries of educators, but does not include 
service education budget. Of the education budget data for 2010-2014 can be concluded that $20 \%$ of the state budget channeled to the education functions as mandated by law.

The health budget is one important element in the implementation of priority health policy applied to RPJMN 2010-2014. Law No. 36 of 2009 Article 170 mentions health financing is aimed at providing sustainable health financing in sufficient amounts, allocated equitably, and utilized as effective and efficient to ensure the implementation of health development to improve the health of society as high. However, the budget for 2010-2014 has not reached the limit of 5\% than mandated by law.

Expenditure in the implementation of Education and Health Functions need for public service standards set out in the minimum service standards in health and education issued by the Ministry of Education and Health.

Quality of service in Islam instructive mandate, keeping promises, and provide optimum service by the commands of Allah in the verses of the Qur'an.

\section{References}

[1] Al-Kaaf, Abdullah Zakiy. Ekonomi dalam perspektif Islam. 2002.CV Pustaka Setia. Bandung. (Economics in an Islamic Perspective)

[2] Direktorat Penyusunan APBN. Dasar - Dasar Praktek Penyusunan APBN di Indonesia. 2013. Kementrian Keuangan. (Basic Practices of APBN Preparation in Indonesia)

[3] Huda, Nurul et al. Keuangan Publik Islam. 2012. Jakarta: Kencana. (Islamic Public Finance)

[4] Huda, Nurul dan Muti, Ahmad. Keuangan Publik Islam: Pendekatan Al-Kharaj(Imam Abu Yusuf). Penerbit Ghalia. Bogor. 2011. (Islamic Public Finance: Al-Kharaj Approach (Imam Abu Yusuf)).

[5] Jusmaliani. Kebijakan Ekonomi Islam. 2005. Yogyakarta, Kreasi Wacana. (Islamic Economic Policy)

[6] Karim, Adiwarman. Sejarah Pemikiran Ekonomi Islam. 2001. IIIT. Jakarta. (History of Islamic Economic Thought)

[7] Keputusan Kementrian Kesehatan No 828/MENKES/SK/IX/2008 tentang Standar Pelayanan Minimal Bidang Kesehatan. (Ministry of Health Decree no. 828/MENKES/SK/IX/2008 on Minimum Service Standart for Healthy Sector)

[8] Mannan, MA. Teori dan Praktek Ekonomi Islam. 1997. Yogyakarta: PT Dana Bhakti Prima Yasa. (Theory and Practice of Islamic Economics)

[9] Nasution, Mustafa Edwin. Pengenalan Eksklusif Ekonomi Islam. 2007. Kencana. Jakarta. (The Exclusive Introduction to Islamic Economics)

[10] P3El. Ekonomi Islam. Rajawali Press. Jakarta. 2009 (Islamic Economics)

[11] Peraturan Kementrian Pendidikan No 63 Tahun 2009 tentang Standar Pelayanan Minimal Bidang Pendidikan. (Ministry of Education Regulation no. 63 Year of 2009 on Minimum Service Standards Education Sector)

[12] Peraturan Pemerintah Republik Indonesia No 96 Tahun 2012 tentang pelaksanaan UU No 25 tahun 2009. (Government Regulation No. 96 Year of 2012 on the Implementation of Law No. 25 of 2009)

[13] afawi, Izhar. Implementasi Undang-Undang No 23 Tahun 2006 Dalam Perspektif EGovernment (Studi Kasus Tentang Pelayanan Kependudukan dan Pencatatan Sipil Di Kabupaten Barito Utara). Tesis. Universitas Lambung Mangkurat. Banjarmasin. (Implementation of Law No. 23 of 2006 in the Government Perspective (Case Study about Population and Civil Registration Service in North Barito District) 
[14] Undang-Undang No 25 Tahun 2009 tentang pelayanan publik. (Law no. 20 of 2009 on Public Service)

[15] http://www.bppk.kemenkeu.go.id/publikasi/artikel/147-artikel-anggaran-danperbendaharaan /20310-anggaran-pendidikan-20-,-apakah-sudah-dialokasikan, accessed on Monday, June 15 $201511.05 \mathrm{pm}$ I (Articles of Budgets and Treasury)

[16] https://www.academia.edu/8697541/EVALUASI_KEBIJAKAN_ANGGARAN_BELANJA_ NEGARA_Studi_Kasus_Anggaran_Belanja_Kementerian_Kesehatan_Dalam_Me ncapai_Target_Rencana_Pembangunan_Jangka_Menengah_Nasional_Bidang_Kes ehatan_Tahun_2010-2014_accessed on Tuesday, June 16201503.18 pm QS. Yusuf:55 (Evaluation of State Budget Policy. Case Study of Health Ministry Expenditure Budget in Achieving a target of the National Medium-Term Development Plan of Health Sector, Year of 2010 to 2014) 